УДК 655.3.022.1

\title{
ПІДГОТОВКА ЗВОЛОЖУВАЛЬНОГО РОЗЧИНУ ТА СИСТЕМ ЗВОЛОЖЕННЯ У ВИРОБНИЧИХ УМОВАХ
}

( Т. О. Дробязко, магістр, О. В. Зоренко, к.т.н., доцент, НТУУ «КПІ», О. Ю. Байдак, к.т.н., доцент, ТОВ «МакХаус», Київ, Україна

\section{Исследованы свойства используемого на предприятии увлажняющего раствора для выбора его оптимального состава, особенности подготовки к печати систем его подачи в печатную машину.}

Properties of a damping liquid used at the enterprise for a choice of its optimum structure, feature of preparation for printing systems of its feed in the printing machine are investigated.

\section{Постановка проблеми}

Глобалізація виробництва, зростаюча динаміка ринку видавничо-поліграфічної галузі спонукають промислові компанії до безперервної інноваційної перебудови своїх виробництв у прагненні пристосувати їх до змін умов на ринку.

Сьогодні як на великих поліграфічних комплексах, так і у приватних малих друкарнях найбільш поширеною залишається технологія офсетного плоского друку завдяки його техніко-економічним особливостям: низька вартість формних процесів; невибагливість до задруковуваної поверхні; висока роздільна і видільна здатності; велика швидкість друку; висока ступінь стандартизації технологічного процесу, що дозволяє його ефективно застосовувати для виготовлення малих та великих накладів одно- й багатофарбової образотворчої продукції зі стабільною якістю відбитків [1].
Але, в той же час, основна характеристика офсетного друку, що відрізняє його від інших способів - зволоження друкарських форм - $є$ частиною загальної проблеми офсетного друку дотримання балансу емульсії «фарба-зволожувальний розчин» (емульсія повинна мати постійний склад та властивості впродовж друку), порушення якого призводить до великих витрат при прилагодженні друкарських машин і отримання неякісної продукції [2].

\section{Аналіз попередніх} досліджень

Для отримання якісних відбитків у офсетному плоскому друці зі зволоженням друкарських форм необхідно дотримуватись таких технологічних умов: задруковуваний матеріал (ЗМ), друкарську фарбу, зволожувальний розчин (ЗР), друкарську форму підбирати у відповідності один до одного і до умов процесу друку; дотримуватись 
кліматичних умов на друкарській ділянці, складах попередньої підготовки до друку ЗМ і фарб; дотримуватись рекомендацій фірм-виробників із застосування добавок у ЗР, фарбу, контролювати їх основні друкарськотехнічні характеристики; стежити за чистотою і регулярною зміною складу ЗР, станом фарбових, зволожувальних валиків та гумовотканниного полотна (ГП), використовуючи відповідні допоміжні фірмові засоби для догляду і змивання; здійснювати візуальний та інструментальний контроль якості відбитків при друкуванні [3-7].

Основні характеристики 3Р, що залежать від його складу і визначають його експлуатаційні показники та в цілому стабільність друкування: кислотність (pH) - оптимальні значення 4,8-5,5 одиниць, а в процесі друкування $\mathrm{pH}$ ЗР змінюється через вплив властивостей ЗМ, фарби, домішок до них, внаслідок корозії металу зволожувального апарату тощо; жорсткість води для виготовлення ЗР - оптимальні значення 5-12 одиниць, надмірні значення призводять до поганого закріплення фарби на відбитку, порушенню роботи валиків, друкарської форми, ГП, появі дефекту тінення зображення тощо; електропровідність - оптимальні значення 800-1500 мкСм, порушення цих значень призводить до емульгування фарби, повільному її закріпленню [2, 5, 6].

Незбалансований склад (надмірна подача) і властивості ЗР призводить не тільки до дефектів на відбитку, але і створюють ряд проблем: утворюється емуль- сія «вода у фарбі», що знижує швидкість висихання фарби і зменшує ії інтенсивність; надлишок ЗР з друкарської форми потрапляє на фарбові накочувальні валики, а звідти - у друкарську фарбу, що починає емульгувати; можливе тінення через зміну властивостей друкарської фарби, особливо при виникненні емульсії «фарба у воді»; виникнення перетискування чи відмарювання фарби; зменшується різкість зображення; деформація (розтягування) задруковуваного матеріалу, що викликає несуміщення фарб на відбитку [4-6, 8, 9].

Для вирішення проблем, пов'язаних зі зволоженням друкарських форм, існує кілька напрямків: удосконалення формного процесу, розробка нових 3Р, автоматичне регулювання процесу подачі ЗР на друкарську форму, удосконалювання конструкцій зволожувальних апаратів, створення друкарських форм, що не потребуватимуть зволоження тощо [1, 5, 10].

Отже, вищезазначене свідчить про те, що процес зволоження, характеристики і склад 3Р, технічний стан і особливості підготовки систем подачі 3Р у друкарську машину є одними з основних чинників, що визначають стабільність процесу друкування та якість відбитків.

\section{Мета роботи}

Дослідження властивостей використовуваного на підприємстві ЗР для вибору його оптимального складу та оптимізація процесу підготовки до друку і роботи систем подачі ЗР. 


\section{Результати проведених досліджень}

ЗР складається 3: води; багатокомпонентних домішок, що включають кислоти, поверхнево-активні речовини, антисептики, антивспінювачі, інгібітори, агентів, що знижують поверхневий натяг; ізопропилового спирту або його замінника. При друкуванні велике значення має не тільки кількість ЗР, що подається на друкарську форму, але і якість його складників (води, домішок).

Вода - одна з головних складових ЗР. Для його підготовки використовується жорстка, півжорстка або м'яка вода, яка може бути водопровідна та артезіанська.

Буферні домішки бувають: для м'якої та півжорсткої води; для жорсткої води; універсальні (для всіх типів води). Крім того вони дозволяють швидко досягти оптимального і стабільного впродовж друкування значення кислотності та мінімізують вплив жорсткості ЗР на якість друку. Так як в офсетному друці багато дефектів на відбитку виникають в результаті надмірного використання домішок, тому їх вміст у ЗР повинен контролюватись (зазвичай 2-3\% від 3Р).

Вибір складу ЗР визначають такі чинники [2]: тип друкарського обладнання (аркушеві, рулонні); системи зволоження традиційні (з чохлами) або спиртові; безконтактні або контактні. При спиртовому зволоженні друкарські машини, як правило, оснащені системою охолодження і рециркуляції ЗР, яка дозво- ляє зменшити кількість спиртової домішки і автоматично контролює і підтримує на заданому рівні кислотність розчину і вміст у ньому спирту; вихідного складу водопровідної води (ії жорсткість, електропровідність); якість складу друкарських фарб; якість, склад і всотувальна здатність 3М; тип друкарських форм (характеристика основи та склад копіювального шару).

Для вибору оптимального відсотку та кількості буферної домішки в умовах лабораторії офсетного друку створювали модель ЗР (табл. 1). Визначення основних показників ЗР проводили із застосуванням наступного обладнання та матеріалів: pH-метр/кондуктометр MPC 227 (Mettler Toledo); тестер «FountControl» для визначення вмісту буферної домішки в розчині; набір ареометрів для визначення густини розчинів; електронні ваги (Mettler Toledo) з ціною поділки 0,0001 г; колби різної ємності; набір буферних розчинів Conductivity standart 1413 мкСм з кислотністю 4,01 та 7,00; калій хлористий за ГОСТ 4234-77; соляна кислота; спирт етиловий за ГОСТ 17299; вода дистильована за ГОСТ 6709-72; стакан ємністю 100 мл за ГОСТ 10394-72; папір фільтрувальний лабораторний за ГОСТ 1202676; термометр скляний за ГОСТ 24104-88; електроплита лабораторна; випробуваний розчин.

Вимірювання кислотності та електропровідності ЗР проводили при температурі $20 \pm 2{ }^{\circ} \mathrm{C}$, концентрація спирту - 3 \%, 5 \%. Вихідні показники води: кислотність - 7,26, електропровід- 


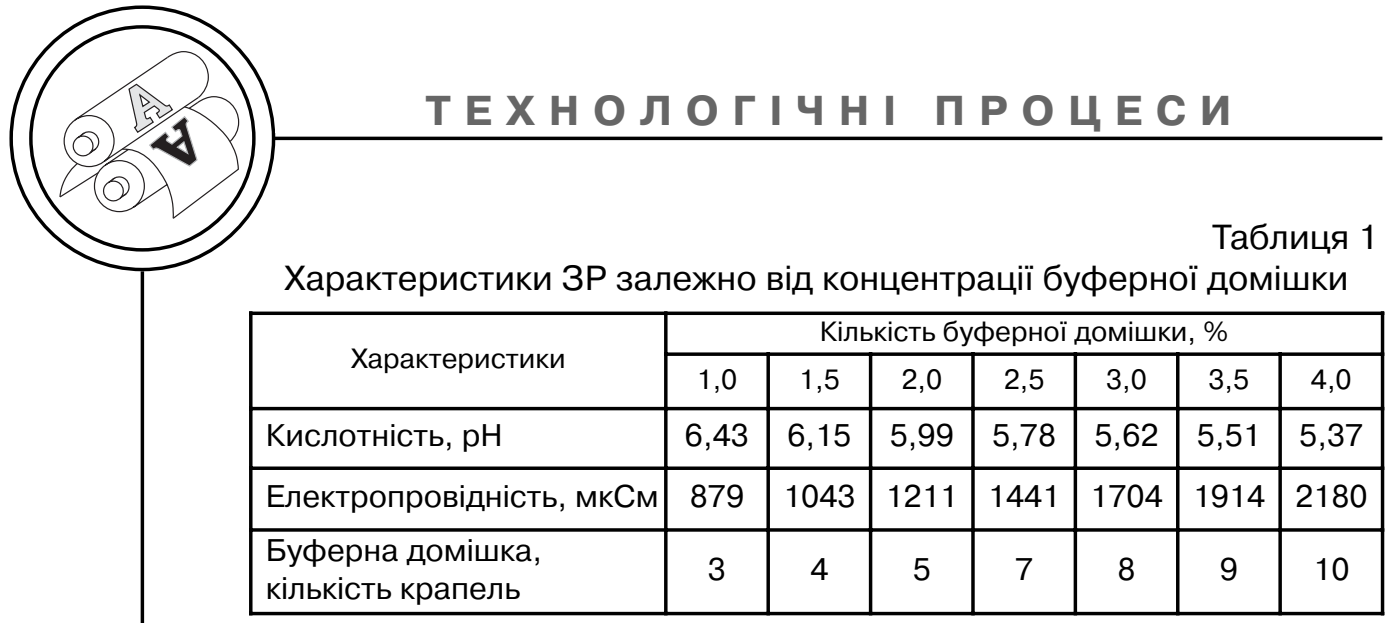

ність - 653 мкСм; буферної домішки: кислотність - 4,35, електропровідність - 27,1 мкСм.

В табл. 2 наведено змодельований ЗР з оптимальними вмістом буферної домішки та спирту і відповідними показниками кислотності, електропровідності, а на рис. 1 - розроблений алгоритм підготовки ЗР в умовах лабораторії.

Дослідження складу ЗР показали, що оптимальна концентрація буферної домішки в умовах лабораторії складає 3,0-3,5 \% при необхідному рівні кислотності - 5,55; 5,57 та електропровідності - 1766; 1648. Отже, після підбору концентрації домішки (табл. 2) на одну каністру води ємністю 25 л необхідно $10 \%$ (2,5 л) спирту та 3,5 \% (1 л) буферної домішки.
На підставі проведених досліджень зі стабілізації складу ЗР та враховуючи проблеми його подачі у системах зволоження типу «Технотранс»/«Балдвін», розроблено рекомендації з обслуговування станції охолодження та подачі ЗР.

Перед запуском станції необхідно добре промити всю систему зволоження (шланги, резервуар холодильника, резервуари зі ЗР у кожній секції друкарської машини). Адже, як було встановлено у дослідженні, якщо злити старий розчин, протерти резервуар холодильника ганчіркою та залити новий розчин, то через кілька годин роботи новий розчин стане брудним. Із зростанням електропровідності рівень рН ЗР у станції змінюється.

Таблиця 2

Моделювання ЗР в лабораторних умовах

\begin{tabular}{|l|c|c|}
\hline \multicolumn{3}{|c|}{ Кількість домішки та ізопропилового спирту, \% } \\
\hline \multicolumn{1}{|c|}{ Характеристики } & $\begin{array}{r}\text { концентрація 3,5 \%-ої } \\
\text { домішки + 3 \%-го спирту }\end{array}$ & $\begin{array}{c}\text { концентрація 3,5 \%-ої } \\
\text { домішки + 5 \%-го спирту }\end{array}$ \\
\hline Кислотність, рН & 5,55 & 5,57 \\
\hline $\begin{array}{l}\text { Електропровідність, } \\
\text { мкСм }\end{array}$ & 1766 & 1648 \\
\hline $\begin{array}{l}\text { Буферна домішка, } \\
\text { кількість крапель }\end{array}$ & 9 & 9 \\
\hline
\end{tabular}




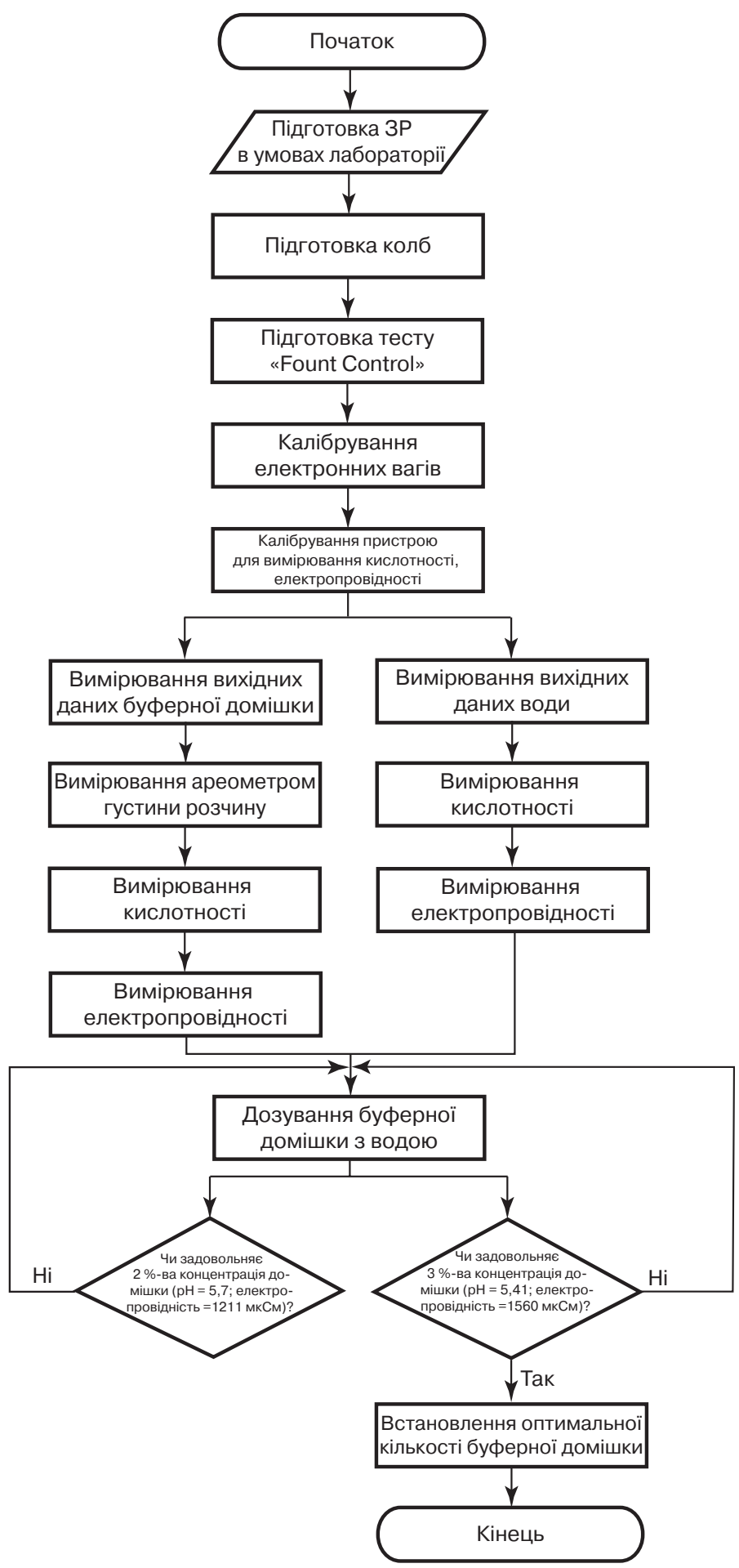

Рис. 1. Алгоритм підготовки ЗР в умовах лабораторії 
Тому, для підтримання стабільних властивостей ЗР у станції потрібно змити ЗР; ретельно вимити резервуар холодильника спеціальним розчином, що розчиняе жири; дотримання правил пожежної безпеки та охорони праці обов'язкове, необхідні також респіратор, гумові рукавички і захисні окуляри.

У холодильниках типу «Технотранс Альфа», а також старих моделях «Балдвін», необхідно ретельно перевіряти і чистити ареометр дозатору. Слід розібрати касету і дістати колбуареометр, де спостерігатиметься шар фарби і бруду. Це, зазвичай, впливає на роботу дозатору. Тобто, він працює некоректно, оскільки вага ареометра змінюється і відбувається неточне дозування спирту в процесі друку. Коли резервуар очищений і знежирений, заливається чиста вода, попередньо відключаються подача спирту та концентрату зволоження. На пульті холодильника встановлюється максимальна температура 11-15 ${ }^{\circ} \mathrm{C}$. При температурі понад $15^{\circ} \mathrm{C}$ спирт буде дуже швидко випаровуватись, тому $€$ небезпека вибуху парів спирту. Заливши воду, додається $10 \%$ очисного розчину, після зливання якого, систему необхідно промити два-три рази чистою водою.

Необхідно слідкувати за станом фільтра для очищення ЗР і за необхідності змінювати на новий, а також двічі на день змивати і чистити валики зволожувального апарату, після чого можна заливати новий ЗР і починати друкарський процес.
Враховуючи вищезазначене розроблено алгоритм підготовки системи зволоження типу «Технотранс»/«Балдвін» (рис. 2).

Операції з очищення систем зволоження в процесі профілактики друкарської машини, необхідно проводити мінімум один раз на місяць, що дозволить отримувати якісну друковану продукцію і заощадити на ремонті обладнання.

Складність регулювання друкарського процесу полягає в тому, що всі чинники взаємопов'язані і залежать один від одного. Відповідно, щоб виявити причини недоліків, які виникають під час друкування, необхідно знати та враховувати всі аспекти, які пов'язані з правильною побудовою всього комплексу робіт з отримання відбитка. Тільки контроль і дотримання всіх параметрів технологічного процесу дозволяють з мінімальними витратами отримати високоякісний відбиток.

\section{Висновки}

В результаті дослідження властивостей використовуваного на підприємстві ЗР запропоновано кількісне співвідношення складників та рекомендації з підготовки до друку і роботи систем подачі ЗР. Розроблено алгоритми підготовки ЗР в лабораторних умовах та системи зволоження в друкарській машині.

Задля уникнення проблем в процесі друкування замовлень: зміни кислотності, електропровідності, кольору зволожувального розчину, порушення балансу «фарба-ЗР», погіршен- 


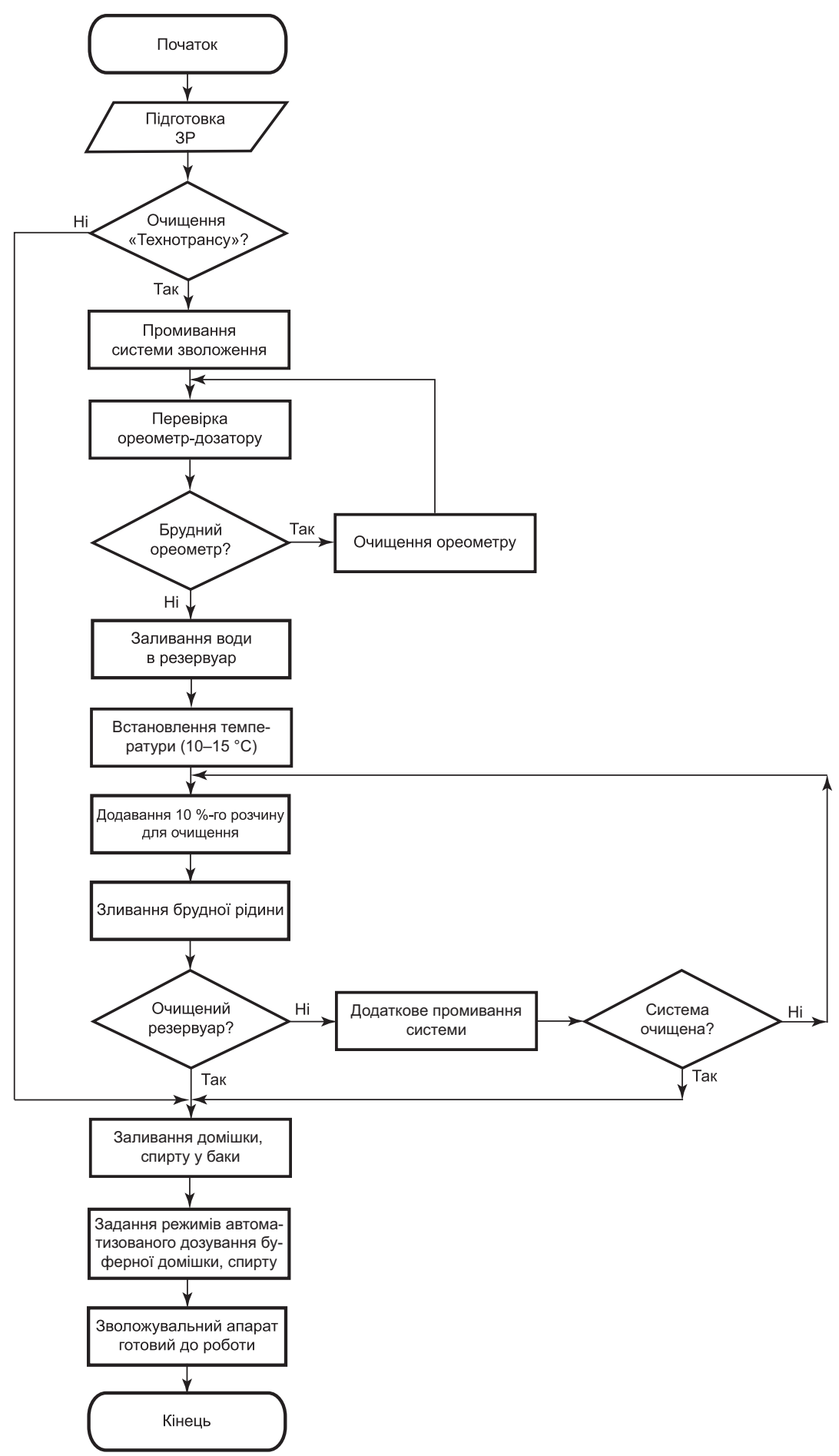

Рис. 2. Алгоритм підготовки системи зволоження в друкарській машині 
ня якості відбитків - тінення, ментальний контроль парамевідбруднювання відбитків у стосі трів ЗР та систематично провотощо, скорочення технологічних дити профілактичне і комплекспростоїв друкарських машин, не очищення систем зволонеобхідно здійснювати інстру- ження.

1. Величко О. М. Видавничо-поліграфічна справа. Практикум з проектування і розрахунку технологічних і виробничих процесів : навч. посіб. / О. М. Величко. - Київ : Видавничо-поліграфічний центр «Київський університет», 2009. - 520 с. 2. Марогулова Н. Н. Расходные материалы для офсетной печати / Н. Н. Марогулова, С. И. Стефанов. - М. : Русский университет, 2002. - 240 с. 3. Губит офсет не краска, губит офсет вода // КомпьюАрт. - 2003. - № 1. - [Електронний ресурс]. - Режим доступу : http://www.compuart.ru. 4. Величко О. М. Опрацювання інформаційного потоку взаємодією елементів друкарського контакту : Монографія / Величко О. М. - К. : ВПЦ «Київський університет», 2005. - 264 с. 5. Мельников О. В. Технологія плоского офсетного друку / Під редакцією д.т.н., проф. Лазаренка Е. Т. - Львів : УАД. - 2007. - 392 с. 6. В. М. Скиба. Параметри зволоження у сучасних офсетних друкарських комплексах / В. М. Скиба, Р. М. Барчук, Т. Г. Осипова, О. М. Величко // Наукові записки. - 2011. - № 4(37). - С. 278-284. 7. О. В. Зоренко. Декелі в офсетному друкарському процесі : Монографія / О. В. Зоренко, О. Ф. Розум. - К. : ВПЦ «Київський університет», 2008. - 168 с. 8. О. М. Величко. Ступінь емульгування і закріплення гібридних фарб / О. М. Величко, О. В. Зоренко, В. Г. Олійник, К. І. Савченко // Технологія і техніка друкарства. - 2010. - № 2(28). С. 120-125. 9. Практика офсетного друку // Бібліотека «Палітри друку». Львів : Палітра друку, 2001. - 264 с. 10. Емельянова Т. Увлажнение в офсетной печати / Емельянова Т. // Полиграфист и издатель. — 2002. - № 10-11. $-41 \mathrm{c.}$

Рецензент - О. М. Величко, д.Т.н., професор, НТУУ «КП।»

Надійшла до редакції 14.09.11 